\title{
Let Your Lawn Tell You When To Water 1
}

\author{
L.E. Trenholm, J. Bryan Unruh²
}

\section{How Often Do I Need to Irrigate?}

People often ask for specific recommendations on how often to irrigate their lawns. There is no simple answer to this, as water requirements vary due to grass species, time of year, geographical location in the state, soil conditions, amount of shade, and overall maintenance level of the lawn. We can draw some broad generalities, but these should be considered guidelines rather than recommendations. Based on research done some years ago, the guideline presented in Table 1 was developed. Again, these intervals will vary depending on all of the variables previously mentioned.

Most homeowners over-water their lawns, which may damage or kill the lawn over time. Excess irrigation is one of the major causes of lawn demise and may include problems such as a shallow root system; increased disease, weed, or insect infestation; reduced drought tolerance; increased thatch and excessive growth; and reduced tolerance to other stresses such as shade and soil problems. To avoid over-watering, look for signs that the lawn needs water.

\section{How Does the Lawn Tell Me When It Needs Water?}

How can you avoid over-watering? The best way is to let your lawn tell you when it needs water. Look for these signs:

1. Lawns under drought stress will curl up their leaf blades in an attempt to minimize leaf area (Figure 1). When leaf blades reach the V-stage is the optimal time to water.

2. Drought-stressed lawns take on a blue-gray cast rather than remaining green.

3. Footprints or tire tracks remain visible on a drought-stressed lawn long after having been made.

As the soil begins to dry out, the lawn will show a lack of available moisture by wilted leaf blades. This condition is evidenced by a lengthwise folding or rolling of the blades, caused by a loss of turgor or water pressure within the plant (Figure 1). Wilting is best seen on the older leaves of the grass plant because the youngest leaf is not fully expanded and will appear as if it is wilted.

1. This document is ENH63, one of a series of the Department of Environmental Horticulture, Florida Cooperative Extension Service, Institute of Food and Agricultural Sciences, University of Florida. Dates reviewed: March 2000; September 2003. Please visit the EDIS Web site at http://edis.ifas.ufl.edu.

2. L.E. Trenholm, assistant professor, Turfgrass Specialist, Environmental Horticulture Department, Cooperative Extension Service, Institute of Food and Agricultural Sciences, University of Florida, Gainesville FL 32611.

J. Bryan Unruh, associate professor, Turfgrass Specialist, West Florida Research \& Education Center.

The Institute of Food and Agricultural Sciences (IFAS) is an Equal Employment Opportunity - Affirmative Action Employer authorized to provide research, educational information and other services only to individuals and institutions that function without regard to race, creed, color, religion, age, disability, sex, sexual orientation, marital status, national origin, political opinions or affiliations. For information on obtaining other extension publications, contact your county Cooperative Extension Service office. Florida Cooperative Extension Service / Institute of Food and Agricultural Sciences / University of Florida / Larry R. Arrington, Interim Dean 


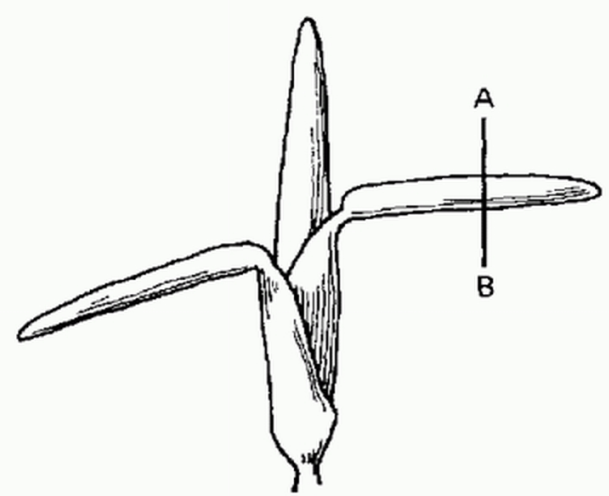

A

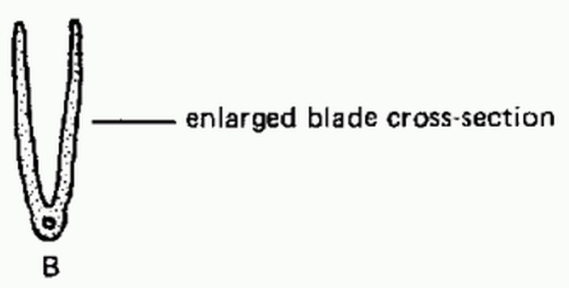

Figure 1. Lawns under drought stress curl up their leaves.

Unless rain is forecast in the next 24 hours, lawns should be irrigated when 30 to 50 percent of the lawn shows signs of wilt. Lawns growing along the coast may require more frequent irrigation due to the increase in wind, which tends to dry the turf out quickly.

\section{How Do I Train My Roots to Grow More Deeply?}

With many parts of Florida now under mandated watering regulations, your lawn may show some signs of requiring irrigation in between watering times. To best prepare your lawn for this, train it to become more drought-tolerant by encouraging deeper roots (Figure 2). Irrigating only when the grass begins to show signs of needing water and watering the proper amount is one way to increase root depth. Another way to encourage deeper rooting is by mowing properly. Mow at the highest recommended height for your grass type and the roots will tend to grow to greater depths.

\section{How Much Water Should I Apply?}

Your objective when irrigating is to get the maximum amount of water to the root zone without over-irrigating. In most Florida soils, this is somewhere between $1 / 2$ to 1 inch of water. Sandy

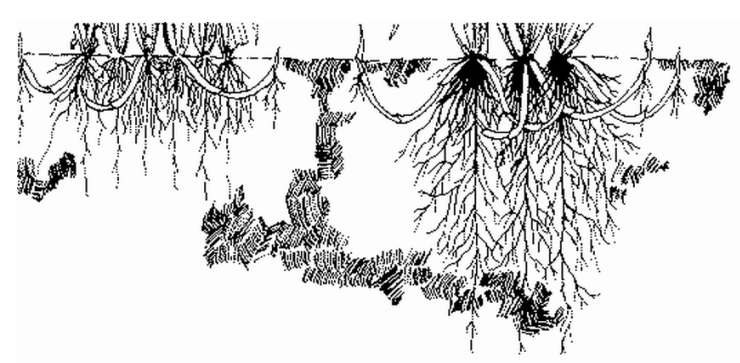

Figure 2. Irrigate and mow to encourage deep rooting.

soils will generally wet to a depth of 12 inches for each inch of water applied. This will target the majority of the root system and encourage more rooting at lower depths. In heavier soils, as are often found in north Florida, less water may be adequate and you might only apply $1 / 2$ to $3 / 4$ inch. In parts of southeast Florida, or wherever there may be hard limestone less than 12 inches below ground, you may also need less water. With less soil, there is no point in trying to encourage deeper rooting.

When watering restrictions limit the frequency with which we can irrigate, some people are tempted to irrigate to the point of run-off. This should never be done, as we are wasting water, encouraging disease and weed problems, and creating potential pollution problems. This is not only wasteful but may also damage or kill your lawn.

To determine how long to run your sprinkler system to apply this much water, set out coffee or tuna fish cans around the perimeter of the sprinkler system and see how long it takes to fill them to the desired depth. Be sure to check your irrigation system for uniform coverage at the same time. Your irrigation system should be zoned separately for turf and ornamentals as irrigation requirements differ between the species. Rain sensors, which are mandatory on all new irrigation systems, should always be functional and in place (Figure 3).

For more information on training your lawn to become more drought tolerant, refer to ENH-157, "Managing Your Florida Lawn Under Drought Conditions" and ENH-57, "Improving Drought Tolerance in Your Florida Lawn." For more details on irrigation practices, refer to ENH-9, "Watering Your Florida Lawn," and ENH-61, "How To Calibrate Your Sprinkler System." 


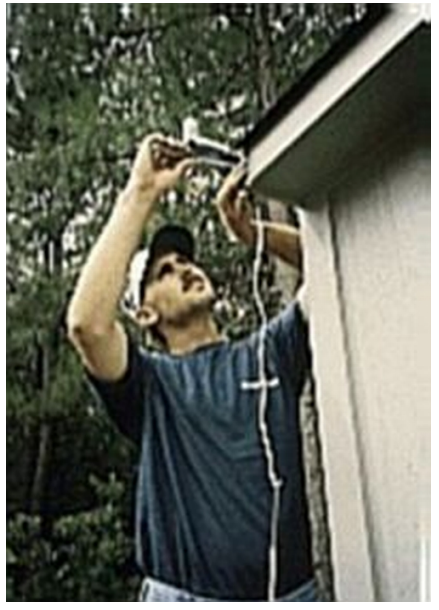

Figure 3. Check to be sure rain sensors are functioning well.

Table 1. Average number of days that St. Augustinegrass with a 6 -inch root system can go without water before becoming drought stressed.

\begin{tabular}{||l|l|l|l||}
\hline \hline & Pensacola & Gainesville & Miami \\
\hline Winter & $8-28$ & $7-23$ & $3-10$ \\
\hline Spring & $3-11$ & $3-9$ & $2-7$ \\
\hline Summer & $1-5$ & $1-5$ & $1-4$ \\
\hline Fall & $2-9$ & $2-8$ & $2-6$ \\
\hline \hline
\end{tabular}

